\title{
Therapeutic Modalities in the management of COVID-19: A worldwide landscape
}

\author{
Juhi Uttamani ${ }^{1}$, Gabriela Fernandes ${ }^{2}$, Shivani Pandey ${ }^{3}$, Venkatasruthi Surabathula ${ }^{4}$, and \\ Divya Bhat ${ }^{5}$ \\ ${ }^{1}$ University of Illinois at Chicago \\ ${ }^{2}$ SUNY Buffalo \\ ${ }^{3}$ Vishwanath Katti Institute Of Dental Sciences, KLE Academy Of Higher Education And \\ Research \\ ${ }^{4}$ Affiliation not available \\ ${ }^{5}$ Nair Hospital Dental College
}

July 7, 2020

\begin{abstract}
Several strains of the novel Coronavirus have been identified and countries around the world are conducting research to identify, map and compare each type. Its infection can manifest with symptoms ranging from uncomplicated non-specific illness to a more damaging syndrome that include mild to moderate pneumonia (Co-vid 19 pneumonia broadly categorised into the phenotypes: L-type and H-type); Acute Respiratory Distress Syndrome; Sepsis and Septic shock. Although, this virus has a low mortality rate, the danger lies in its virulence and transmission dynamics. With more and more cases being reported, researchers and clinicians are promptly identifying and triaging the cases for treatment. Till date, there has been no drug identified to be efficacious cure for this infection. Using the WHO guidelines as a base, various medical institutions are continuously updating their guidelines for the identification and therapeutic management of persons infected with Co-vid 19, with a strong emphasis on IPC measures. The guidelines also highlight detailed supportive treatment including supplemental oxygen therapy, ventilation, intubation and management of specific complications. The current treatment is tailored to patient centred management for the existing co-morbidities and appreciate a progress in the prognosis. What is needed at this hour however, is a definitive drug therapy or vaccine. Different countries are rushing to find this and various trials are already underway. The aim of this article is thus to review salient features of specific therapies being used now and summarise the different clinical trials being conducted so as to stay abreast of the possible treatment modalities.
\end{abstract}

\section{1| INTRODUCTION}

Since December 2019, an outbreak of a new human virus has spread in many countries and has led to thousands of cases and deaths ${ }^{1}$. The novel coronavirus officially named as COVID-19 that started from Wuhan, China has spread to more than 211 countries \& territories around the world ${ }^{1}$. Severe acute respiratory syndrome coronavirus-2 (SARS COV-2), the causative agent of COVID-19, was declared a pandemic by the World Health Organization on 11th March 2020 and is a major global health concern. Most people who are infected show mild respiratory symptoms that eventually disappear on their own, but some people develop more severe illness, like pneumonia ${ }^{2}$. The virus is spread through contact with an infected person or via respiratory droplets through coughs or sneezes. Although protective measures have been executed all throughout the world (such as isolation of confirmed and suspected cases, education about handwashing techniques and importance of wearing masks, prevention of large gatherings, \& lockdowns) to reduce the spread of the virus, the need for an effective treatment is crucial to stop the pandemic and reduce the morbidity and mortality 
of COVID-192. Since the onset of the outbreak, researchers have suggested many agents that might have an efficacy against COVID-19. Different antiviral, antimicrobial, \& immunomodulatory agents were included in the latest guidelines of various countries. According to the World Health Organization, there is no specific medicine to prevent or treat coronavirus disease (COVID-19) yet ${ }^{3-6}$.

The management of symptoms may include the use of antipyretics or anti- inflammatory medicines for fever \& mild pain and oxygen therapy for patients with respiratory distress and has asked to implement mechanical ventilation depending on the patient's clinical condition ${ }^{7}$. However, an array of drugs permitted for other conditions, as well as multiple investigational agents, are being studied for the treatment of COVID-19 in several clinical trials around the world ${ }^{8-12}$. The treatment protocols across various countries are very similar and most of them have suggested the study and use (as a part of compassionate use) of drugs like Hydroxychloroquine, Chloroquine phosphate, Remedesivir, and Lopinavir/Ritonavir ${ }^{6,12-16}$. There have been an increasing number of studies rapidly published online and in educational journals; however, there is limited and insufficient evidence specifically around the therapeutic management for COVID-19. The purpose of the review is to retrospectively study the various treatment modalities taking place for patients infected by the virus, in the worst affected countries of the world.

\section{2| SARS-CoV-2: Virology and Drug Target}

Corona virus has glycoprotein spikes on its surface which gives the virus "Crown" like appearance, hence CORONA VIRUS ${ }^{17}$. This virus is supposed to have a ZOONOTIC origin. Genetically it has been revealed that Covid-19 genetically clusters with BETACORONA VIRUS, subgenus SERBACOVIRUS, together achieved with two bat-derived strains ${ }^{8}$. SARS-CoV-2 is named so because it is genetically similar to SARS Coronavirus that was responsible for SARS outbreak 2002. SARS-CoV-2 is a single stranded RNAenveloped virus, which targets its host cells through the viral structural spike(S) protein that binds to the angiotensin-converting enzyme 2 (ACE2) receptors. The ACE2 receptors are abundantly present in lungs and glandular cells of gastric, duodenal and rectal epithelium as well as endothelial cells and enterocytes of small intestine. ACE2 is also present in brain and there has been results showing effects of COVID-19 on brain. Encephalopathy has been reported in few patients after they have been detected with the virus by cerebrospinal fluid assay ${ }^{18}$. ACE2 receptors are largely present in the heart and are involved in heart function. A high incidence of thrombosis and venous thromboembolism has been noted in patients with severe COVID-19 in the ICUs. After binding to ACE2, the virus than uses the host cell receptor and endosomes to enter the cells and this is facilitated by a host type 2 transmembrane serine protease, TMPRSS2, via $\mathrm{S}$ protein. Clinical laboratory findings of COVID-19 resulted in high levels IL-2, IL-7 and IL-6, elevated levels of granulocyte-macrophage colony stimulating factor (GM-CSF) and tumor necrosis factor-alpha suggestive of cytokine release syndrome ${ }^{18}$. People with COVID-19 have classical serum biomarkers, elevated C-reactive protein (CRP), lactate dehydrogenase (LDH), D-dimer and Ferritin. Involvement of the kidney has also been recorded in post-mortem studies. Once the virus has entered the host cells, it synthesizes the viral polyproteins that encode for the replicase-transcriptase complex. This virus synthesizes its RNA via RNA-dependent RNA polymerase ${ }^{18}$. The drug targets include nonstructural proteins for example- 3-chymotrysin-like protease, papain-like protease and RNA-dependent RNA polymerase, which shares similarities with COVID-19. Other target drug therapies could be immune regulation pathways.

\section{3| REVIEW OF DRUGS and THERAPIES}

(Repurposed, Investigational \& Adjunctive Therapies)

\section{ANTIMALARIAL DRUGS}

\section{Hydroxychloroquine/chloroquine (with or without Azithromycin)}

Hydroxychloroquine/chloroquine serves its antiviral activity by changing the $\mathrm{pH}$ of endosomes and is believed to prevent viral entry, transport, and post-entry events. They are prescription drugs that have been used for treatment of malaria and certain inflammatory conditions. The studies revealed that chloroquine may reduce glycosylation of ACE2, thereby preventing COVID-19 from effectively binding to host cells ${ }^{19-21}$. In addition, 
chloroquine might block the production of pro-inflammatory cytokines thereby blocking the pathway that subsequently leads to acute respiratory distress syndrome (ARDS). These drugs are under investigation in clinical trials for pre-exposure or post-exposure prophylaxis of SARS-CoV-2 infection, and treatment of patients with mild, moderate, and severe COVID-1922, 23. According to NIH there are insufficient clinical data to recommend either for or against using chloroquine or hydroxychloroquine for the treatment of COVID-19. ${ }^{24}$

Benefits: In the current available data based on clinical trials of Hydroxychloroquine, a somewhat higher proportion in the HCQ group experienced clinical improvement. However, the certainty in the evidence was rated as very low mainly due to small sample sizes (sparse data), co-interventions, and risk of bias due to methodological limitations. The other benefits of the drug are that it has low toxicity, is safe in pregnancy, is cheaper at cost and has fewer side effects.

Harm: A few studies described significant QT prolongation in patients treated with HCQ, some cases resulting in a QT increase to over $500 \mathrm{~ms}$, which led to discontinuation of the HCQ treatment, illustrating the high risk for clinically relevant arrhythmias. Other side effects include headache, dizziness, nausea, vomiting, and stomach pain, loss of appetite, skin rash.

Conclusion: There are currently 84 ongoing trials on the drug Hydroxychloroquine in the countries that were reviewed in this article ${ }^{24}$. Hydroxychloroquine has showed effects in fighting pneumonia, improving lung imaging findings and providing short duration of disease time. The recommended dose for hydroxychloroquine for COVID-19 is $500 \mathrm{mg}$ two times a day for 10 days recommended by experts. Because of the potential for toxicity, the NIH and IDSA guidelines panel recommends that the HCQ+AZ combination only be used in the context of a clinical trial. FDA issued an Emergency Use Authorisation (EUA) for the use of chloroquine andhydroxychloroquinefor treatment of hospitalized adults and adolescents (weight [?]50 kg) with COVID-19 for whom a clinical trial is not available. The prescribing health care provider is responsible for submitting patient outcome reports and all serious adverse events and medication errors should be reported to FDA's medical product safety reporting program as described in the Emergency Use Authorization.

\section{HIV PROTEASE INHIBITOR}

\section{Drugs - Lopinavir/Ritonavir}

In studies conducted in China, Lopinavir and Ritonavir used in treatment of COVID-19 has showed no remarkable effects on the COVID-19 ${ }^{25}$.Lopinavir/ritonavir a trug approved for usage for the treatment of HIV, demonstrated in-Vitro activity against other novel corona viruses via inhibition of 3-chymotrypsin-like protease $^{25}$. The most commonly studied lopinavir/ritonavir dosing regimen for treatment of COVID-19 is $400 \mathrm{mg} / 100 \mathrm{mg}$ twice daily for up to 14 days. Other antiretrovirals, including protease inhibitors and integrase strand transfer inhibitors, were recognized by enzyme activity screening as having SARS-CoV-2 activity. In vitro cell models demonstrated activity of darunavir against SARS-CoV-2. The NIH and IDSA Panel recommends against the use of lopinavir/ritonavir or other HIV protease inhibitors (AIII) for the treatment of COVID-19, except in the context of a clinical trial ${ }^{25}$.

Benefits : According to one RCT and two case studies analysed by the IDSA, treatment with lopinavir/ritonavir failed to show or exclude a beneficial effect on mortality, although failure of clinical improvement was lower in the study group that was treated with lopinavir.

Harm : lopinavir/ritonavir have shown effects like gastrointestinal adverse reactions, including anorexia, nausea, abdominal discomfort, or diarrhea. The risk of hepatic injury, pancreatitis, severe cutaneous eruptions, QT prolongation, and the potential for multiple drug interactions due to CYP3A inhibition, are all well documented with this drug combination.

Conclusion: There are 15 ongoing drug trials of the drugs Lopinavir/Ritonavir in the countries reviewed ${ }^{25}$. The guidelines panel recommends the use of lopinavir/ritonavir only in the context of a clinical trial. 
Additional clinical trials or prospective outcome registries are needed for an approval of treatment with lopinavir/ritonavir and other HIV-1 protease inhibitors for patients with COVID-19

\section{ANTIVIRAL DRUGS}

\section{Drugs- Remdesivir/Umifenovir/ Favipiravir}

Remdesivir binds to the viral RNA-dependent RNA polymerase, inhibiting viral replication through premature termination of RNA transcription. This drug was also used as the emergency drug in first covid19 positive patient detected in the United States of America and there were improvements seen in the condition of the patient ${ }^{26}$. Umifenovir also known as Arbidol has showed more promising results as antiviral drug with a unique mechanism of targeting the S protein/ACE2 interaction and inhibiting membrane fusion of the viral envelope $^{27,28}$. The current dose of $200 \mathrm{mg}$ orally every 8 hours for influenza is being studied for COVID-19 treatment. This drug is currently being used for treatment of influenza in china with unsuccessful results.

Benefits and Harm: A recent case series of 53 patients with severe COVID-19 pneumonia who received remdesivir under a compassionate-use protocol reported clinical improvement in $68 \%$ after a median followup of 18 days, with $13 \%$ mortality and a generally acceptable toxicity profile. Remdesivir can cause GI symptoms (e.g., nausea, vomiting), elevated transaminases, and prothrombin time elevation (without change in international normalized ratio $[\mathrm{INR}])$.

Conclusion : NIH declared Remdesivir as an investigational antiviral drug for COVID19 and recommends it in the context of a clinical trial ${ }^{29,30}$. There are 24 clinical trials of these drugs, ongoing in the countries reviewed.

\section{CORTICOSTEROIDS}

\section{Drugs- Dexamethasone/ Methylprednisolone/ Prednisone}

Administration of corticosteroid treatment in Co-Vid patients can most definitely said to be case based. Studies have shown that the use of a low dose of corticosteroids for "shock reversal" in patients having septic shock has improved their mortality rate and outcome ${ }^{31}$. However, evidence has also shown that there is little to no improvement and possible harm (due to immunosuppressive effects) in such a regimen when used for patients without $\mathrm{ARDS}^{32}$. ISDA suggests against the use of corticosteroids for patients admitted with COVID19 pneumonia whereas it recommends its use for patients with ARDS due to COVID19, but only in the context of clinical trials. Guidelines suggest a typical corticosteroid regimen in adults with Co-Vid 19 and septic shock: Generally, IV Hydrocortisone $200 \mathrm{mg} /$ day is administered in intermittent doses or as an infusion $^{33}$.

Benefits and Harms : Various studies were declared inconclusive by IDSA due to lack of critical information and variability seen in the treatments provided. Steroids and IL-6 inhibitors can be immunosuppressive and may increase risk of secondary infections. Steroids in certain cases have been seen to produce long term side effect such as osteonecrosis.

Conclusion: Carefully designed studies \& prospective outcome registries are needed to determine the dose, route, timing, and duration of such treatment on the prevention of clinical deterioration. According to IDSA and NIH, if a person is on a steroid (inhaled or systemic) for another indication (e.g., asthma), the steroid should be continued. There are 12 ongoing clinical studies based on corticosteroids.

\section{MONOCLONAL ANTIBODIES}

Drugs-Sarilumab/Bevacizumab/Tocilizumab/ Nivolumab/Leronlimab/Itolizumab/ Gimsilumab/Clazakizumab/ Meplazumab

Monoclonal antibodies synthesised in the laboratory mimic natural antibodies. Studies reporting on the pathogenesis of SARS and MERS-CoV suggest a release of proinflammatory cytokines including interleukins6 (IL-6) during the clinical illness ${ }^{34}$. An antibody-based treatment has the potential to provide immediate effect in a COVID positive patient. The spike protein on the SARS-CoV-2 virus is the main target being 
explored for potential COVID-19 monoclonal antibodies ${ }^{35}$. The aim is to target the spike protein and the antibody will be able to neutralise and affect the capacity of the virus to infect healthy cells. A retrospective analysis of 20 severe cases of COVID-19 showed that treatment with tocilizumab led to a reduction in fever and lung lesion opacity, and recovered the percentage of lymphocytes in peripheral blood ${ }^{36}$.

Benefits : According to the study, treatment with tocilizumab may have reduced mortality, as there were no deaths reported. However, this conclusion remains uncertain given the lack of a control group or adjustments for confounding factors.

Harm : This particular retrospective study did not report any serious adverse events. However, patients receiving tocilizumab are often at an increased risk of serious infections (bacterial, viral, invasive fungal infections, and tuberculosis) and hepatitis B reactivation. Cases of anaphylaxis, severe allergic reactions, severe liver damage and hepatic failure, and intestinal perforation have been reported after tocilizumab administration in patients without COVID-19.

Conclusion : The USA Guidelines panel recommends the use of Tocilizumab only in the context of clinical trials. There are 68 clinical trials ongoing on the various drugs with properties of monoclonal antibodies.

\section{NUCLEOSIDE INHIBITORS}

\section{Drug-Ribavirin}

Ribavirin is a guanine analogue that inhibits viral RNA-dependent RNA polymerase ${ }^{37}$. The clinical experiments with Ribavirin have shown remarkable results regarding its activity against COVID-19. Nevertheless, its effect against SARS-CoV was limited as it required high dosage to serve its anti-viral activity that is 1.2 $\mathrm{g}$ to $2.4 \mathrm{~g}$ orally every 8 hours and needed combination therapy. This drug can be given orally, intravenous and enteral routes. No evidence has been available for inhalational Ribavirin. Many studies conducted to check for the efficiency and side effects of this drug and few studies concluded that this drug has possible harm due to its adverse effects including HEMATOLOGIC and LIVER TOXICITY ${ }^{38}$.

Harm : Many studies conducted to check for the efficiency and side effects of this drug and few studies concluded that this drug has possible harm due to its adverse effects including HEMATOLOGIC and LIVER TOXICITY. Ribavirin causes severe hematologic toxicity and liver toxicity depending on the dose given. The high doses given in the treatment of SARS resulted in hemolytic anemia in patients, patients treated with Ribavirin plus Interferons for MERS required blood transfusion, in some, Ribavirin for SARS showed raise in transaminase elevation. Ribavirin shows teratogenic activity and is contraindicated in pregnancy. Hence, Ribavirin given with combination therapy shows best results than given alone.

Conclusion : Ribavirin was used in the treatment of MERS and has shown good results but its efficiency to treat COVID-19 is still questionable and studies in china are being carried out to check its efficacy. There are currently 26 clinical trials ongoing in China alone.

\section{IMMUNOMODULATORS}

\section{Therapy-IFN Beta $1 A$ \& $1 B / N K$ cells/PEG-IFN- Lamba}

Interferons Alpha2b have been studied for $\mathrm{nCoVs}$, most studies have shown its good results in combination therapy with drugs like Ribavirin, lopinavir and Ritonavir ${ }^{39,40}$. But delayed treatment will result in its decreased efficiency towards the disease same as other agents.

Harm : You should not use the combination of interferon alfa-2b and ribavirin if you have:

Severe kidney disease, blood cell disorders such as thalassemia or sickle cell anaemia, allergy to interferons or ribavirin, if you are pregnant as interferon with ribavirin causes miscarriage, if you have liver disease as the combination causes cirrhosis or hepatitis, colitis and other intestinal problems.

Conclusion: The in-vitro data and animal data and the absence of clinical trials have been the reason to not 
include interferons currently as a treatment modality. There are 7 clinical trials on various immunomodulators against COVID-19.

\section{PASSIVE IMMUNE THERAPY}

\section{Therapy-Convalescent Plasma}

Hyperimmune immunoglobulin or convalescent plasma is the serum specific antibodies of IgG for SARSCOVID and can be obtained from Co-Vid 19 patients who have recovered ${ }^{41,42}$. The level of antibody titre required to neutralise SARS COVID remains unknown. This was previously used in the treatment of MERS, SARS and H1N1 (2009) with favourable results. The IDSA guideline panel recommends COVID-19 convalescent plasma in the context of a clinical trial. Doctors are currently using this line of treatment on compassionate grounds. Cases where it was used on critically ill patients have proven to have promising results.

Benefits : IDSA identified a study that had one group of patients that were treated with convalescent plasma and another one as a control group. The study showed that there was a $30 \%$ mortality in the control group as compared to no death in the group that was administered with the plasma treatment. A recent case series also showed five critically ill patients with laboratory confirmed COVID-19 (who had ARDS) improved after receiving plasma transfusion. Their body temperature came down to normal within 3 days (in 4 of 5 patients) and there were no detectable viral loads within 12 days. No serious adverse reactions or safety events were recorded following COVID-19 convalescent transfusion.

Harms : The risks associated with plasma transfusions such as fever, a small risk of infectious disease transmission, mild to severe allergic reactions, transfusion-related lung injury (TRALI) and transfusion associated circulatory overload (TACO).

Conclusion: Based on the countries reviewed, there are 20 ongoing interventional studies with convalescent plasma. Due to low overall certainty of evidence, additional research and clinical trials will be required before convalescent plasma is used as a confirmed treatment plan for COVID19. US FDA has approved convalescent plasma treatment for investigational use under the traditional Investigational New Drug Applications (IND) regulatory pathway, and for eligible patients who have confirmed COVID-19 and severe or immediately life-threatening conditions such as respiratory failure, septic shock, and/or multiple organ dysfunction or failure.

\section{MESENCHYMAL STEM CELL THERAPY}

Currently, stem cell therapy has become a promising therapeutic field, which is showing various opportunities to cure incurable diseases ${ }^{43}$. MSCs has called for attention due to source potential, a high proliferation rate, the need of a less invasive procedure, and free of ethical issues. There is much superiority in using MSC therapy $^{44-46}$ in comparison with other treatments which includes - I) Easily access and can be isolated from various tissues such as bone marrow and adipose tissues, umbilical cord, dental pulp, menstrual-blood, buccal fat pad, foetal liver, etc. II) They are multipotent stem cells; III) MSCs can easily grow to clinical volume in the required period; IV) MSCs can be stored for repetitive therapeutic usage; V) Clinical trials of MSCs so far have not shown adverse reactions. Following the COVID-19, the virus may lead to a destroying immune overreaction in the body. In COVID-19 patients, the immune system produces large amounts of inflammatory factors in an overproduction of immune cells and cytokines. There are 8 clinical trials currently ongoing on mesenchymal stem cell therapy.

\section{KINASE INHIBITORS}

\section{Drugs - Nintedanib esilate/Imatinib/Ruxolitinib/Baricitinib/ Acalabrutinib}

Kinase Inhibitors are enzyme inhibitors that block the action of specific enzymes. They have proven to be efficacious in various chemotherapy treatments because of their ability to inhibit phosphorylation of amino acids, thereby playing a critical role in preventing the progression of several cancers. A large number of trials are being conducted on Nintedanib esilate, which is a small molecule kinase inhibitor whose use has 
primarily been approved in treatment of idiopathic pulmonary fibrosis ${ }^{47,48}$. Though results of the trials for their use in CoVid-19 are yet to come, these are highly targeted drugs and are being used in treating the comorbidities associated with the disease such as pulmonary fibrosis, hyperinflammation, pulmonary vascular leak, etc ${ }^{49,50}$. It is important to note that the safety profile of the use of these drugs in these patients is yet to be seen. Known side effects include liver toxicity; endocrine disturbances such as thyroid disorders, glucose metabolism disorders; low blood cell counts; reduced bone density; fertility problems, etc. There are a total of 17 trials being carried out in the countries reviewed in this article.

\section{ANGIOTENSIN RECEPTOR BLOCKERS (ARB'S)}

Drugs- Losartan/ Telmisartan/ Valsartan

Angiotensin converting enzyme 2 (ACE2) is the receptor for SARS CoV-2 on human cells due to which there is a possibility that the Angiotensin receptor Blocker drugs may increase the likelihood of acquiring SARS-CoV-2 or may exacerbate the course of COVID-19 ${ }^{51,52}$. However, until now, there are no clinical data to support this hypothetical concern. For this reason, the American Heart Association, the Heart Failure Society of America and the American College of Cardiology all recommend that ACE inhibitors or ARBs should be continued in people who have an indication for these medicines. There are 6 clinical trials of the Angiotensin Receptor Blocker drugs and 2 trials on the drug Captopril (ACE Inhibitor) currently registered in the countries reviewed.

\section{l) SYSTEMIC OXYGEN THERAPY}

\section{Therapy-Hyperbaric Oxygen}

Hyperbaric oxygen therapy is a treatment that is used as an adjunct to standard therapies ${ }^{53,54}$. It involves the administration of $100 \%$ oxygen in a pressurised room or via a tube. It is often used in the treatment of chronic wounds (like those associated with diabetes), radiation or reperfusion injuries, decompression sickness, etc. It's potential use in CoVid 19 patients is on the basis of its ability to generate an increase in the number of oxygen free radicals - stimulating the release of growth factors that can promote wound healing, diminish inflammatory response through a variety of mechanisms, ultimately improving neovascularisation and post-ischaemic tissue survival ${ }^{54,55}$. Preliminary evidence from China when used on patients suggested that when administered (once or in a series of treatments) hyperbaric oxygen therapy increased oxygen saturation in the blood and reversed disease progression. However, more studies need to be conducted in this regard to confirm its beneficial capacity to infected patients. Though it remains relatively safe, possible side effects include lung damage, CNS or oxygen toxicity, middle ear barotrauma (MEB), and changes in vision $^{55-59}$. There are currently 10 clinical trials being carried out in the countries reviewed.

\section{m) VACCINES}

According to COVID-19 tracker by raps.org (Last updated on June 01, 2020), two vaccines are in between phases 2 and 3 one of which is Bacillus Calmette-Guerin (BCG) live-attenuated vaccine by University of Melbourne and Murdoch Children's Research Institute; Radboud University Medical Center; Faustman Lab at Massachusetts General Hospital and the other AZD1222 studied by The University of Oxford. The mRNA-1273 vaccine by Moderna is in phase 2 trial and Ad5-nCoV (by CanSino Biologics), INO-4800 (by Inovio Pharmaceuticals), BNT162 (by Pfizer and BioNTech), and PiCoVacc ( by Sinovac) vaccines are in their phase 1 or between phase 1 and 2 of trials. Rest of the vaccines being studied are in a pre-clinical or at an early research phase. There are 9 interventional clinical trials on vaccines that are registered and ongoing in the countries reviewed in the article.

\section{4| COUNTRY-WISE REVIEW OF ONGOING CLINICAL TRIALS}

The search terms COVID-19 OR SARS-COV-2 on ClinicalTrials.gov showed 1359 registered clinical trials worldwide (as of May 12 $2^{\text {th }}$ 2020) of which 808 were interventional studies (including recruiting, not yet recruiting and completed), 534 were Observational studies and 17 were of the type Expanded Access. Out of these, 49 studies were in the Phase 4 of the clinical trial. The article aimed at reviewing and describing the 
ongoing Clinical trials in the major affected countries by COVID-19. The countries studied and researched upon are USA, Spain, Italy, France, Germany, UK, Iran, China and India.

\section{USA}

Hydroxychloroquine/chloroquine (with or without Azithromycin)

A total of 33 out of 125 interventional studies were on the repurposed drug Hydroxychloroquine either individually, in combination or in comparison with other drugs like Chloroquine Sulfate, Azithromycin,Indomethacin, Dietary Supplement with Vitamin C/Zinc, lopinavir/ritonavir, Losartan and Ascorbic Acid. A single ongoing study was also seen on the drug chloroquine individually.

Lopinavir/Ritonavir

There is currently 1 ongoing trial on the drug Lopinavir/Ritonavir in combination with other drugs such as Hydroxychloroquine and Losartan in Bassett Medical Center Cooperstown, New York, United States. (i) COVID MED Trial - Comparison Of Therapeutics for Hospitalized Patients Infected With SARS-CoV-2.

\section{Corticosteroids}

According to ClinicalTrials.gov, a single ongoing trial of the drug Methylprednisolone was seen taking place in Mayo Clinic in Rochester Rochester, Minnesota, United States which was titled: (i) Steroid Dosing by biomarker Guided Titration in Critically Ill Patients With Pneumonia.

\section{Tocilizumab}

4 clinical trials are taking place in the United States of America on the immunomodulatory drug of Tocilizumab and 1 trial each on the drugs Leflunomide, Sirolimus, Gimsilumab, Clazakizumab, and two trials on the drugs Leronlimab, and Sarilumab.

\section{Convalescent Plasma}

8 clinical trials showing promising results are seen with respect to the treatment modality of Covalescent Plasma. (i)Convalescent Plasma as Treatment for Hospitalized Subjects With COVID-19 Infection. (ii) Convalescent Plasma vs. Placebo in Emergency Room Patients with COVID-19. (iii) Convalescent Plasma in ICU Patients with COVID-19-induced Respiratory Failure. (iv) Convalescent Plasma in the Treatment of COVID 19. (v) COVID-19 Convalescent Plasma. (vi) Passive Immunity Trial of Nashville II. (vii) Plasma Therapy of COVID-19 in Critically Ill Patients. (viii) Convalescent Plasma vs. Standard Plasma for COVID-19.

\section{Remdesivir}

5 ongoing clinical trials are seen with the antiviral drugs Remdesivir \& Favipiravir.

(i)Study to Evaluate the Safety and Antiviral Activity of Remdesivir (GS-5734) in Participants With Severe Coronavirus Disease (COVID-19). (ii) Study to Evaluate the Safety and Antiviral Activity of Remdesivir (GS-5734) in Participants with Moderate Coronavirus Disease (COVID-19) Compared to Standard of Care Treatment. (iii) Adaptive COVID-19 Treatment Trial (ACTT). (iv) Study of the Use of Favipiravir in Hospitalized Subjects With COVID-19. (v) Oral Favipiravir Compared to Standard Supportive Care in Subjects With Mild COVID-19.

\section{Angiotensin Receptor Blockers (ARB's)}

A total of 5 Clinical trials on ARBs are ongoing with drugs like Losartan (4) and Telmisartan (1). (i) Study of Open Label Losartan in COVID-19. (ii) Losartan for Patients with COVID-19 Requiring Hospitalization. (iii) Losartan for Patients with COVID-19 Not Requiring Hospitalization. (iv) Do Angiotensin Receptor Blockers Mitigate Progression to Acute Respiratory Distress Syndrome With SARS-CoV-2 Infection. (v) Pilot Clinical Trial of the Safety and Efficacy of Telmisartan for the Mitigation of Pulmonary and Cardiac Complications in COVID-19 Patients. 


\section{Mesenchymal Stem Cell Therapy}

5 ongoing clinical trials are seen on the effect of mesenchymal stem cell therapy in successful treatment of COVID positive patients. (i)A Randomized, Double-Blind, Placebo-Controlled Clinical Trial to Determine the Safety and Efficacy of Hope Biosciences Allogeneic Mesenchymal Stem Cell Therapy (HB-adMSCs) to Provide Protection Against COVID-19. (ii) A Clinical Trial to Determine the Safety and Efficacy of Hope Biosciences Autologous Mesenchymal Stem Cell Therapy (HB-adMSCs) to Provide Protection Against COVID-19. (iii) Use of UC-MSCs for COVID-19 Patients. (iv) Efficacy and Safety Study of Allogeneic HBadMSCs for the Treatment of COVID-19. (v) Mesenchymal Stromal Cells for the Treatment of SARS-CoV-2 Induced Acute Respiratory Failure (COVID-19 Disease).

\section{Vaccines}

There are 4 interventional vaccine studies ongoing as of June $4^{\text {th }} 2020$. Two clinical trials are on the safety and Immunogenicity of the vaccine mRNA-1273 for prophylaxis of SARS-Cov2. One trial is based on the safety, tolerability and immunogenicity of INO-4800 for COVID-19 which is being conducted in healthy volunteers and One is a study to describe the safety, immunogenicity and potential efficacy of RNA vaccine (BNT162a1, BNT162b1, BNT162b2, BNT162c2) candidates against COVID-19 in healthy adults.

Ongoing clinical trials for other drugs \& treatment modalities in USA.

Hyperbaric Oxygen Therapy (2), SGLT2 inhibitors - Dapagliflozin (1), Kinase inhibitors- Baricitinib (1) / Ruxolitinib (1), Povidone-Iodine nasal spray (2), Nitric oxide inhalation therapy (3), Antifibrinolytic Tranexamic acid (2), Antiprotozoal - Atovaquone (1), CGRP receptor antagonist - Vazegepant (1), Selective serotonin reuptake inhibitor - Fluvoxamine (1), Pegylated interferon lambda (2), Human amniotic fluid (1), Ascorbic acid (3), DPP4 inhibitor -Linagliptin (1), Estrogen patch (1)Nerokinin -1 antagonist -Tradipitant (1), vasoactive intestinal polypeptide -Aviptadil (1), Anti-gout- Colchicine (1), Selinexor (1), Corticosteroid -Methylprednisolone (1), BCG vaccine (1).

\section{SPAIN}

A single trial of Acalabrutinib : An interventional randomized study included 428 individuals in Barcelona, Spain. Acalabrutinib- administered orally or receive delivery of emptied capsule via nasogastric (NG) or an enteral feeding tube.

A single trial of Indirect Endovenous Systemic Ozone : Interventional randomized study included 50 participants in SEOT Valencia, Spain. $200 \mathrm{ml}$ at $40 \mathrm{mcg} / \mathrm{ml}$ of medical ozone / oxygen in $200 \mathrm{ml}$ of patients' blood mixed in a homologated device for the procedure.

Inclusion criteria: COVID-19 patients detected with virus in oro/nasopharynx. Mild ill according to WHO numeric scale. Mild ill according to Berlin criteria. Non-intubated patients.

Exclusion criteria: Patient treated with systemic ozone in last 6 months. Patients having side effects with ozone. Glucose-6-dehydrogensase deficiency. Pregnant women.

5 trials of Sarilumab : Interventional randomized study conducted in 300 patients hospitalized with pneumonia. Age criteria was 18 years and above. Study conducted both in Italy and Spain.

\section{ITALY}

A single trial of ACE inhibitors, Angiotensin II Type-I Receptor Blockers : An observational study conducted by IRCCS Neuromed, Department of Epidemiology and Prevention, Italy, amongst 5000 participants. Estimated study start date was March 23, 2020, estimated primary completion date- April 10, 2020 and estimated study completion date- April 30, 2020.

Patients who developed severe COVID-19 respiratory disease were included in this study. Control group included patients who did not develop severe COVID-19 respiratory disease. 
2 trials of Hyper Immune Plasma : An interventional study amongst 49 individuals who were critically infected by COVID-49 was included in this trial by Catherine Klersy, Pavia, PV, Italy.

Inclusion criteria: Age above 18 years. Positive for RT-PCR for SARS-CoV-2 for less than 10 days. PCR increased by 3.5 with respect to baseline or $>18 \mathrm{mg} / \mathrm{dl}$. Need for continuous ventilation or CPAP. Signed informed consent.

Exclusion criteria: Moderate to severe ARDS lasting more than 10 days. Proven hypersensitivity reaction to hemoderivatives or immunoglobulins. Consent not received. Administration of hyperimmune plasma at day 1 and based on clinical response on day 3 and 5 .

A single trial of Escin : Escin is a mixture derived from horse chestnut seed (HCSE). Contains compounds such as protoescigenin, barringtogenol, alpha and beta Escin, cryptoescin and benzopyrones. It is an interventional study conducted amongst 120 individuals at Luca Gallelli, Catanzaro, Italy. Age groups included was $18-75$ years. Females who are pregnant or breastfeeding were excluded.

Oral Escin group: Standard therapy + escin tablet $40 \mathrm{mg}^{*} 3$, os for 12 days.

Parenteral Escin group: Standard treatment + sodium Escinate $20 \mathrm{mg}$ iv/day for 12 days.

A single trial of Bevacizumab : An interventional study conducted amongst 20 individuals at MoriggiaPelascini Gravedona hospital in Italy. Age groups included was 18-80 years.

Bevacizumab $500 \mathrm{mg}+$ normal saline (NS) 100ml, iv drip [?] 90min.

\section{FRANCE}

According to the latest updates $(26 / 04 / 2020)$, France has the $4^{\text {th }}$ highest number of COVID positive cases in the world. In the article 'Clinical and virological data of the first cases of COVID-19 in Europe: a case series', the researchers give a history of usage of the drug Remdesivir for the first few COVID positive patients detected in France. The duration of drug delivery was different for each patient and the drug was discontinued for most of the patients after a few days due to mild side effects seen and due the fear of risk. Continued research and successful clinical trials are required to validate a treatment for Covid19.

France currently has 121 clinical trials on the subject of COVID19 out of which 25 (after elimination of overlapping, serological tests and unrelated trials) are drug interventional studies. There are 9 trials studying Hydroxychloroquine, 3 trials on Corticosteroids (Dexamethasone(2) and prednisone(1)), 3 ongoing studies on the antiviral drug Remdesivir, 5 studies on various immunomodulators (Nivolumab(1), Sarilumab(3) \& Tocilizumab), 1 trial each on Convalescent plasma, Hyperbaric oxygen, Dornase alpha inhalation solution, Mesenchymal stromal cells, and the drug captopril.

\section{UNITED KINGDOM}

Hydroxychloroquine: (i) ChemoPROphyLaxIs For covId-19 infeCtious disease (the PROLIFIC trial) (ii) Platform Randomised trial of INterventions against COVID-19 In older people ${ }^{60}$ (iii) An adaptive Phase 2/3, randomized, open-label study assessing efficacy and safety of hydroxychloroquine for hospitalized patients with moderate to severe COVID-19 [HYDROXYCHLOROQUINE SULFATE]

Remdesivir : 3 trials studying use of Remdesivir -

(i)A Multicenter, Adaptive, Randomized Blinded Controlled Trial of the Safety and Efficacy of Investigational Therapeutics for the Treatment of COVID-19 in Hospitalised Adults [Remdesivir - active drug Triphosphate]. (ii) Phase 3 Randomized Study to Evaluate the Safety and Antiviral Activity of Remdesivir (GS-5734) in Participants with Moderate COVID-19 Compared to Standard of Care Treatment. (iii) A Phase 3 Randomized Study to Evaluate the Safety and Antiviral Activity of Remdesivir (GS-5734) in Participants with Severe COVID-19.

Vaccine : 1 trial studying a vaccine ChAdOx1 nCoV-19 - A phase I/II study to determine efficacy, safety and immunogenicity of the candidate Coronavirus Disease (COVID-19) vaccine ChAdOx1 nCoV-19 in UK 
healthy adult volunteers.

Actilyse : 1 trial studying use of Actilyse (Alteplase) - A pilot, open label, phase II clinical trial of nebulised recombinant tissue-Plasminogen Activator (rt-PA)in patients with COVID-19 ARDS: The Plasminogen Activator COVID-19 ARDS (PACA) trial

SNG001 : 1 trial studying use of SNG001 (IFN $\beta-1$ a for nebulisation) - A randomised double-blind placebocontrolled trial to determine the safety and efficacy of inhaled SNG001 (IFN $\beta-1$ a for nebulisation) for the treatment of patients with confirmed SARS-CoV-2 infection (COVID-19)

Tocilizumab : 1 trial studying use of Tocilizumab

(i) A Randomized, Double-Blind, Placebo-Controlled, Multicenter Study To Evaluate The Safety And Efficacy Of Tocilizumab In Patients With Severe Covid-19 Pneumonia.

Multiple therapeutics : 4 trials studying multiple therapeutics

(i) Preventing Pulmonary Complications in Surgical Patients at Risk of COVID-19 : This trial is being conducted with Lopinavir- Ritonavir; Hydroxychloroquine (Plaquenil)

(ii) Randomised Evaluation of COVID-19 Therapy (RECOVERY): This trial is being conducted with Lopinavir/ritonavir, Dexamethasone, Hydroxychloroquine, Azithromycin, Prednisolone, Hydrocortisone, RoActemra (Tocilizumab)

(iii) ACCORD 2: A Multicentre, Seamless, Phase 2 Adaptive Randomisation Platform Study to Assess the Efficacy and Safety of Multiple Candidate Agents for the Treatment of COVID 19 in Hospitalised Patients: Bemcentinib, human immunoglobulin (Ig) G1 monoclonal antibody (mAb), Acalabrutinib, Zilucoplan, Heparin

(iv) Randomized, Embedded, Multifactorial, Adaptive Platform trial for Community-Acquired Pneumonia: Ceftriaxone, Moxifloxacin Hydrochloride, Levofloxacin Hemihydrate, Piperacilin-tazobactam, Ceftaroline, Amoxicillin-Clavulanate, Azithromycin, Clarithromycin, Hydrocortisone

\section{GERMANY}

At the time of writing this, Germany had the $5^{\text {th }}$ highest number of COVID positive cases. The clinical trials being carried out, with at-least 1 trial focussing on vaccines, are as follows:

Tocilizumab : 2 trials on the monoclonal antibody therapy Tocilizumab are being carried out -

(i) A prospective, randomized, double blinded placebo-controlled trial to evaluate the efficacy and safety of tocilizumab in patients with severe COVID-19 pneumonia

(ii) A Randomized, Double-Blind, Placebo-Controlled, Multicenter Study to evaluate the safety and efficacy of Tocilizumab in patients with severe Covid-19 Pneumonia

Remdesivir : trials on the anti-viral Remdesivir

A Phase 3 Randomized Study to Evaluate the Safety and Antiviral Activity of Remdesivir (GS-5734) in Participants with Moderate COVID-19 Compared to Standard of Care Treatment

A Phase 3 Randomized Study to Evaluate the Safety and Antiviral Activity of Remdesivir (GS-5734) in Participants with Severe COVID-19

Convalescent plasma : 1 trial on convalescent plasma (i) A randomized, prospective, open label clinical trial on the use of convalescent plasma compared to best supportive care in patients with severe COVID-19

Hydroxychloroquine : 1 trial on the anti-malarial Hydroxychloroquine (i) Randomized controlled trial of hydroxychloroquine versus placebo for the treatment of adult patients with acute coronavirus disease 2019 - COVID-19 
Valsartan : 1 trial on the Angiotensin Receptor Blocker (i) Treatment of Sars-CoV2 infections (Covid19) with valsartan vs placebo, a three-armed randomized, partly blinded trial.

Sarilumab : 1 trial on the Monoclonal antibody therapy (i) An adaptive phase 3, randomized, double-blind, placebo-controlled, study assessing efficacy and safety of sarilumab for hospitalized patients with COVID-19.

Multiple drugs : 1 trial on multiple drug therapies (i) Randomized, Embedded, Multifactorial, Adaptive Platform trial for Community-Acquired Pneumonia (REMAP-CAP)

The drugs whose therapeutic actions are being studied are - Levofloxacin, Hydrocortisone, Ceftriaxone, Azithromycin, Clarithromycin, Erythromycin, Amoxicilline-Clavulante, Piperacillin-Tazobactam, Roxithromycin, Ceftaroline, Moxifloxacin, Oseltamivir Phosphate, Lopinavir/Ritonavir, Anakinra, Interferon Beta-1a.

Vaccine : (i)A Multi-site Phase I/II, 2-Part, Dose-Escalation Trial Investigating the Safety and Immunogenicity of four Prophylactic SARS-CoV-2 RNA Vaccines Against COVID-2019 Using Different Dosing Regimens in Healthy Adults. Human trials for this m-RNA vaccine have begun as of April $23^{\text {rd }}, 2020$. There are 4 candidates available for trial: BNT162a1, BNT162b1, BNT162b2, BNT162c2. The BNT162 targets the Spike protein and Receptor Binding Domain (RBD) of SAR-CoV-2.

\section{IRAN}

According to the Article "An Algorithmic Approach to Diagnosis and Treatment of Coronavirus Disease 2019 (COVID-19) in Children: Iranian Expert's Consensus Statement", certain drugs and their dosages have been mentioned for the management of the virus specifically in children. Treatment for patients who were admitted in intensive care unit included combined antiviral agents and immunomodulators [oseltamivir + hydroxychloroquine + Kaletra (lopinavir + ritonavir) $] \pm$ ribavirin and if necessary, antibiotics were used according to the patient's situation. There are various ongoing drug trials in the pursuit of finding a effective treatment against the virus.

There are 11 clinical trials which include 10 drug interventions as follows:

1 trial on the drug Deferoxamine (i) Application of Desferal to Treat COVID-19.

1 trial on Favipiravir Favipiravir in Hospitalized COVID-19 Patients.

1 trial Azithromycin (i) Azithromycin in Hospitalized COVID-19 Patients.

1 completed and 1 ongoing trial on Interferon Beta 1A \& 1B (i) An Investigation Into Beneficial Effects of Interferon Beta 1a, Compared to Interferon Beta 1b And The Base Therapeutic Regiment in Moderate to Severe COVID-19: A Randomized Clinical Trial. (ii) Interferon Beta 1a in Hospitalized COVID-19 Patients.

1 trial on the drug Umifenvir (i) Umifenovir in Hospitalized COVID-19 Patients.

1 trial on the drugs Levamisole Pill + Budesonide+Formoterol inhaler (i) Evaluation of Efficacy of Levamisole and Formoterol+Budesonide in Treatment of COVID-19.

An ongoing trial on colchine (i) The Effects of Standard Protocol With or Without Colchicine in Covid-19 Infection.

1 clinical trial on Colvalescent Plasma (i) Investigating Effect of Convalescent Plasma on COVID-19 Patients Outcome: A Clinical Trial.

\section{CHINA}

Chloroquine phosphate/ Hydroxychloroquine : Total 32 trials have been conducted by China for Chloroquine phosphate/Hydroxychloroquine.A multicenter, single-blind, randomized controlled clinical trial at Beijing you'an Hospital, Capital Medical University. 
Hyperbaric oxygen therapy : A Total of 7 clinical trials have been seen to be taking place for Hyperbaric oxygen Therapy. Dr. Zhong Mangling published promising results with hyperbaric oxygen therapy at the Department of Hyperbaric Oxygen in Wuhan Yangtze River Shipping General Hospital. The COVID-19 patients were treated with hyperbaric oxygen for 90-120mins with a dose of 1.4 to 1.fi ATA. The results were encouraging as the patients showed remarkable results in fighting hypoxemia COVID-19 can cause.

Natural Killer cells (NK): A single Clinical trial conducted at First Affiliated Hospital of Xinxiang Medical University. Participants will receive conventional treatment plus twice a week of NK cells $(0.2 * 10 \mathrm{E} 7 \mathrm{NK}$ cells $/ \mathrm{kg}$ body weight). The eligibility criteria for this experiment will be male or female of age between 18-65 years, pneumonia which is judged by radiograph or computed tomography and laboratory confirmation of NCP infection by reverse-transcriptase polymerase chain reaction (RT-PCR) from any diagnostic sampling source.

The exclusion criteria will be patients who is pregnant or breastfeeding, patient with HIV, HBV or HCV infection, malignancy, psychosis, patients participating in other clinical trials and the patients with inability to provide informed consent or to comply with test requirements.

Nintedanib esilate soft capsules: 13 trials of Nintedanib esilate soft capsules have been seen in China. A singlecenter, randomized, placebo-controlled trial at Tongji Hospital of Tongji Medical College, Huazhong Science and Technology University conducted in the treatment of pulmonary fibrosis in healed moderate to severe patients of novel coronavirus pneumonia (COVID-19). Nintedanib is used to treat idiopathic pulmonary fibrosis. Nintedanib cloth sulfonate soft capsule treatment: according to the drug manual recommendation, give nintedanib cloth sulfonate soft capsule $150 \mathrm{mg}$ twice daily with an interval of about 12 hours each time. Continuous medication for 8 weeks. Changes were seen in forced vital capacity (FVC) after treatment compared to baseline.

Inclusion criteria for this study group 18-70 years old individuals regardless of gender, infection with novel coronavirus confirmed by throat swab nucleic acid test, CT examination of patients with multiple fibrotic shadows in both lungs and signed informed consent.

Exclusion criteria were previous history of chronic bronchitis, emphysema, interstitial lung disease or pulmonary heart disease, people with active peptic ulcer, mental illness and pregnancy and lactation.

Allogeneic Human Dental Pulp Mesenchymal Stem Cells : There is a single ongoing trial in china for this treatment modality. To treat severe novel coronavirus pneumonia (COVID-19) patients at Renmin Hospital of Wuhan University. Intravenous injection of 3.0x10e7 human dental pulp stem cells solution (30ml) on day 1 , day 4 and day 7 , based on routine treatment of COVID-19.

Intravenous saline injection (Placebo)- Intravenous injection of $3 \mathrm{ml}$ of $0.9 \%$ saline on day 1 , day 4 and day 7 , based on routine treatment of COVID-19. The estimated completion of the study is to be noted by 31 May 2021, which started at 31 December 2020.

A single trial on Qi-Mai-Fei-Luo-Ping mixture in the improvement of lung function: A multicenter, randomized, double-blind, parallel-controlled trial at Hubei Provincial Hospital of TCM, assessing the the improvement of lung function of the novel coronavirus pneumonia (COVID-19). The mixture consist of PORK and SILVER CARP fish minced separately with food processor after removal of fat and connective tissue. Pork and fish were mixed with food processor at a speed of 18,000 revolutions per minute for 2 mins and mixing proportion were 10:0, 7:3, 5:5, 3:7and 0:10 pork/fish ratio.)

2 clinical trials with Heparin anticoagulation and high dose vitamin $C$ treatment : Shanghai Hospital Management and Zhongnan Hospital for COVID-19. Low-molecular-weight-heparin 1 to $2 \mathrm{mg} / \mathrm{kg}$ per day, continued until the patient's D-dimer level returned to normal. Once fibrinogen degradation product (FDP) [?] 10 microgram/ml and D-dimer [?] 5 microgram/ml, switch to unfractionated heparin. Vitamin C is administered at a dose of 50 to $100 \mathrm{mg} / \mathrm{kg}$ per day and continued until significant improvement in the oxygenation index.

20 trials with Anti-CD147 Humanized Meplazumab injection : To treat 2019-nCoV pneumonia at Tang- 
Du Hospital. The primary drug used is meplazumab. The secondary drug used is methylprednisolone. Remarkable end point results were achieved.

\section{INDIA}

Hydroxychloroquine : 4 trials studying Chloroquine or Hydroxychloroquine

(i) An open labelled RCT to study the effect of Chloroquine in addition to standard therapy in COVID-19 patients

(ii) To study Topical Chloroquine Nasal Drops in early stage COVID019 and its impact on viral load and cure rates

(iii)An open labelled, RCT to study Hydroxychloroquine for the prevention of new infection and also its adverse outcomes

(iv) Usage of Hydroxychloroquine And Azithromycin In Indicated Confirmed Covid-19 Positive Cases For Its Efficacy In Early Negative Conversion- Pilot Observational Study AIIMS Raipur

Convalescent Plasma : 4 trials studying Convalescent Plasma-

(i)A single arm clinical trial to evaluate the safety and efficacy of convalescent plasma in COID-19 patients

(ii) An RCT to study the safety and efficacy of Convalescent Plasma Therapy in Severely Sick COVID-19 Patients

(iii)A Phase II, Open Label, Randomized Controlled Trial to Assess the Safety and Efficacy of Convalescent Plasma to Limit COVID-19 Associated Complications in Moderate Disease

(iv) An Open Label Randomised Control Trial on Passive Immunization with Convalescent Plasma In Severe Covid-19 Disease

$B C G$ vaccine : 3 trials studying $\mathrm{BCG}-$

(i) A Multicentre, Phase III, Double Blind, Randomised, Placebo- Controlled Study to Evaluate the efficacy of recombinant BCG VPM1002 in reducing infection incidence and disease severity of SARS_COV-2/COVID19 among high risk subjects

(ii) A double blind randomised parallel group, Placebo-controlled trial to study the effect of BCG- Denmark (Green Signal) on prevention of COVID 19 infection in health care workers

(iii)A non-randomised Phase 2 Clinical Trial for the Evaluation of BCG as potential therapy for CoVID-I9

Homeopathy

(i)A cluster, randomized trial proving the efficacy of Homeopathic treatment in prevention and cure of COVID-19 [Arsenic Album 30]

(ii) A Clinical Trial to ascertain the effect of Homoeopathic Medicines in prevention of outbreak of symptoms in asymptomatic Corona virus and suspected Corona virus patients [Arsenic Album, Bryonia Alba, Gelsemium, Antimonium Tartaricum, Crotalus Horridus]

(iii) A Clinical Trial To Study The Efficacy Of Homoeopathic Medicine In Prevention And Cure Of Corona Virus Disease 19 [Arsenic Album 30]

(iv)Homoeopathy as adjuvant in management of Covid-19 infection

(v)Randomized, Parallel Group, Active Controlled trial on effects of homeopathic medicine made from cadamba on COVID-19 
Ayurveda: The Ayurvedic remedies make use of various medicinal plants that have benefits in controlling fever and other flu like symptoms. Arsenic Album 30 is used in Homeopathy for treatment of flu. 3 trials studying therapies of alternative medicine -Ayurveda

(i)A single arm trial for Evaluation of effect of composite AYUSH treatment as Prophylaxis of COVID-19 Study.

(ii)A Randomized controlled Single blinded prospective multi-centre clinical trial to investigate the safety and efficacy of ZingiVir-H as an adjuvant therapy in hospitalized adults diagnosed with coronavirus disease 2019 (COVID-19) [Ayurvedic remedies -Samshamani vati, Sudarshan Ghana Vati, Khadiradi vati, Murrchita Tila taila and Homeopathic medicine - Arsenic album 30]

(iii) A Non-randomized, Active Controlled study to assess the effectiveness of Ayurvedic formulation in addition to standard of care in COVID-19 positive patients in a tertiary hospital.

Imatinib : 1 trial studying Imatinib - Efficacy of Imatinib in mild SARS CoV2 infection: A randomized study. Imatinib is a tyrosine kinase inhibitor. In-vitro studies carried out have shown it to be a potent inhibitor for SARS and MERS.

Ivermectin : Ivermectin is an anti-parasitic drug that has erstwhile been used in the treatment of parasitic infestations such as Onchocerciasis, Filariasis, Pin worms, Head lice and Rosacea. Ivermectin potentiates GABA neurotransmission responses. In-vitro studies done have revealed that it also displays an anti-viral action through specifically inhibiting IMP $\alpha / \beta 1$-mediated nuclear import. There is a single non-randomised active controlled trial to study the effectiveness of Ivermectin with standard of care treatment versus standard of care treatment for COVID-19 cases.

SSV Formulation : 1 trial studying a nutraceutical formulation - SSV Formulation- An open labelled trial to evaluate the safety and efficacy of SSV Formulation to boost immunity in quarantine patients of COVID-19. Not much is known about the exact formulation of this nutraceutical.

Co-infection with Mycobacterium : (i) A Randomized, Parallel Group, Placebo Controlled Clinical Trial of Mycobacterium w in Critically ill COVID 19 Patients

Niclosamide: (i)A randomise trial to evaluate the effect of Oral Niclosamide in mild and very mild COVID-19 cases

Itolizumab: (i) A Multi-Centre, Open label, Two Arm Randomized, Pivotal Phase 2 Trial to Study the Efficacy and Safety of Itolizumab in COVID-19 Complications

\section{5| CONCLUSION}

COVID-19, the pandemic, has created a ravagement in the world by being so contagious in its manner. COVID-19 represents the greatest deadly pandemic of this generation. The number of clinical trials conducted, as highlighted in Table 1, in order to investigate or obtain a potential treatment line for this pandemic highlights both the need and the capability to be able to come up with a high quality research in the middle of such pandemic. Unfortunately, no therapies have been proven one-hundred percent effective till date and the research of the potential treatment plan is still in progress. But with the help of supportive therapies and few trusted drugs, the treatment of COVID-19 has become possible to some extent. The advancement in preparation of vaccines has also contributed a lot to the hope towards cure of the disease. Many countries which are affected the most by the pandemic are continuously working towards the research and possibility to find the cure. China, India, The United States Of America, United Kingdom, and many other countries are successful in putting vaccines for trial for COVID-19. The clinical trials mentioned above are current on-going trails as of May 10, 2020. The drugs like Hydroxychloroquine, Lopinair/Ritonavir, Nintedanib esilate, Bevacizumab, Sarilumab, Ribavirin, Convalescent plasma therapy and Hyperbaric oxygen therapy are widely and commonly used in many countries for trails in the treatment of COVID-19 due to their promising results to an extent. These drugs are helpful in treating COVID-19 patients who has mild to moderate symptoms. The patients with severe COVID-19 symptoms were treated with hyperbaric oxygen 
and much combination of drugs above. Tocilizumab has been proven effective in many studies to treat severe COVID-19 as it has shown promising results. The scientists are working day and night to obtain an effective vaccine or drug in order to control and stopping the pandemic as soon as possible. Keeping in mind the low effectiveness of many drugs to fight coronavirus, social distancing, maintaining personal hygiene and sanitization and maintaining immunity levels is the only and best way to control the spread of the disease.

Acknowledgements

The authors do not have any financial interest in the companies whose materials were used in the included studies.

Conflict of interest

No conflicts declared. The study was self-funded.

References:

1. Hu Y, Sun J, Dai Z, et al. Prevalence and severity of corona virus disease 2019 (COVID-19): A systematic review and meta-analysis. Journal of clinical virology : the official publication of the Pan American Society for Clinical Virology . Jun 2020;127:104371. doi:10.1016/j.jcv.2020.104371

2. Jan H, Faisal S, Khan A, et al. COVID-19: Review of Epidemiology and Potential Treatments Against 2019 Novel Coronavirus. Discoveries . Apr 26 2020;8(2):e108. doi:10.15190/d.2020.5

3. Mirzaei R, Karampoor S, Sholeh M, Moradi P, Ranjbar R, Ghasemi F. A contemporary review on pathogenesis and immunity of COVID-19 infection. Molecular biology reports . Jun 29 2020;doi:10.1007/s11033020-05621-1

4. Milanesio M, Escudero D, Caeiro JP. [Covid-19 disease. Report of the first confirmed case in Cordoba (Argentina) and literatura review]. Revista de la Facultad de Ciencias Medicas . May 8 2020;77(2):110112. Enfermedad covid-19. Reporte del primer caso confirmado en Cordoba (Argentina) y revision de la literatura. doi:10.31053/1853.0605.v77.n2.28421

5. Mehta NS, Mytton OT, Mullins EWS, et al. SARS-CoV-2 (COVID-19): What do we know about children? A systematic review. Clinical infectious diseases : an official publication of the Infectious Diseases Society of America. May 11 2020;doi:10.1093/cid/ciaa556

6. Mehta N, Mazer-Amirshahi M, Alkindi N, Pourmand A. Pharmacotherapy in COVID-19; A narrative review for emergency providers. The American journal of emergency medicine. Apr 15 2020;doi:10.1016/j.ajem.2020.04.035

7. Azam SA, Myers L, Fields BKK, et al. Coronavirus disease 2019 (COVID-19) pandemic: Review of guidelines for resuming non-urgent imaging and procedures in radiology during Phase II. Clinical imaging . Jun 1 2020;67:30-36. doi:10.1016/j.clinimag.2020.05.032

8. Oliveira BA, Oliveira LC, Sabino EC, Okay TS. SARS-CoV-2 and the COVID-19 disease: a mini review on diagnostic methods. Revista do Instituto de Medicina Tropical de Sao Paulo . 2020;62:e44. doi:10.1590/S1678-9946202062044

9. Nascimento Junior JAC, Santos AM, Quintans-Junior LJ, Walker CIB, Borges LP, Serafini MR. SARS, MERS and SARS-CoV-2 (COVID-19) treatment: a patent review. Expert opinion on therapeutic patents . Jun 7 2020:1-13. doi:10.1080/13543776.2020.1772231

10. Mahase E. Covid-19: Quarantine works when introduced early alongside other measures, finds review.Bmj . Apr 9 2020;369:m1450. doi:10.1136/bmj.m1450

11. Mahase E. Covid-19: WHO halts hydroxychloroquine trial to review links with increased mortality risk.Bmj . May 28 2020;369:m2126. doi:10.1136/bmj.m2126 
12. Mahalmani VM, Mahendru D, Semwal A, et al. COVID-19 pandemic: A review based on current evidence.Indian journal of pharmacology . Mar-Apr 2020;52(2):117-129. doi:10.4103/ijp.IJP_310_20

13. Md Insiat Islam R. Current Drugs with Potential for Treatment of COVID-19: A Literature Review. Journal of pharmacy \& pharmaceutical sciences : a publication of the Canadian Society for Pharmaceutical Sciences, Societe canadienne des sciences pharmaceutiques . 2020;23(1):58-64. doi:10.18433/jpps31002

14. Maldonado E, Tao D, Mackey K. Antithrombotic Therapies in COVID-19 Disease: a Systematic Review. Journal of general internal medicine. Jun 17 2020;doi:10.1007/s11606-020-05906-y

15. Mahase E. Covid-19: Medical leaders call for rapid review to prepare for second wave. Bmj . Jun 24 2020;369:m2529. doi:10.1136/bmj.m2529

16. Liu W, Zhou P, Chen K, et al. Efficacy and safety of antiviral treatment for COVID-19 from evidence in studies of SARSCoV-2 and other acute viral infections: a systematic review and meta-analysis. CMAJ : Canadian Medical Association journal = journal de l'Association medicale canadienne. Jun 3 2020;doi:10.1503/cmaj.200647

17. LoPresti M, Beck DB, Duggal P, Cummings DAT, Solomon BD. The Role of Host Genetic Factors in Coronavirus Susceptibility: Review of Animal and Systematic Review of Human Literature. medRxiv : the preprint server for health sciences . Jun 3 2020;doi:10.1101/2020.05.30.20117788

18. Sarvepalli D. Coronavirus Disease 2019: A Comprehensive Review of Etiology, Pathogenesis, Diagnosis, and Ongoing Clinical Trials. Cureus . May 12 2020;12(5):e8076. doi:10.7759/cureus.8076

19. Patel TK, Barvaliya M, Kevadiya BD, Patel PB, Bhalla HL. Does Adding of Hydroxychloroquine to the Standard Care Provide any Benefit in Reducing the Mortality among COVID-19 Patients?: a Systematic Review. Journal of neuroimmune pharmacology : the official journal of the Society on NeuroImmune Pharmacology . Jun 30 2020;doi:10.1007/s11481-020-09940-9

20. Wright C, Ross C, Mc Goldrick N. Are hydroxychloroquine and chloroquine effective in the treatment of SARS-COV-2 (COVID-19)? Evidence-based dentistry . Jun 2020;21(2):64-65. doi:10.1038/s41432-020-00982

21. Galvis V, Spinelli FR, Tello A, et al. Hydroxychloroquine as Prophylaxis for Coronavirus SARSCoV-2 Infection: Review of the Ongoing Clinical Trials. Archivos de bronconeumologia . May 31 2020;doi:10.1016/j.arbres.2020.05.008

22. Allahyari A, Rahimi H, Khadem-Rezaiyan M, et al. Effect of hydroxychloroquine on COVID-19 prevention in cancer patients undergoing treatment: a structured summary of a study protocol for a randomised controlled trial. Trials . Jun 26 2020;21(1):575. doi:10.1186/s13063-020-04485-x

23. Prayuenyong P, Kasbekar AV, Baguley DM. Clinical Implications of Chloroquine and Hydroxychloroquine Ototoxicity for COVID-19 Treatment: A Mini-Review. Frontiers in public health . 2020;8:252. doi:10.3389/fpubh.2020.00252

24. Bienvenu AL, Marty AM, Jones MK, Picot S. Systematic review of registered trials of Hydroxychloroquine prophylaxis for COVID-19 health-care workers at the first third of 2020. One health . Dec 2020;10:100141. doi:10.1016/j.onehlt.2020.100141

25. Yao TT, Qian JD, Zhu WY, Wang Y, Wang GQ. A systematic review of lopinavir therapy for SARS coronavirus and MERS coronavirus-A possible reference for coronavirus disease-19 treatment option. Journal of medical virology. Jun 2020;92(6):556-563. doi:10.1002/jmv.25729

26. Liang C, Tian L, Liu Y, et al. A promising antiviral candidate drug for the COVID-19 pandemic: A mini-review of remdesivir. European journal of medicinal chemistry . Jun 6 2020;201:112527. doi:10.1016/j.ejmech.2020.112527 
27. Lian N, Xie H, Lin S, Huang J, Zhao J, Lin Q. Umifenovir treatment is not associated with improved outcomes in patients with coronavirus disease 2019: a retrospective study. Clinical microbiology and infection : the official publication of the European Society of Clinical Microbiology and Infectious Diseases . Jul 2020;26(7):917-921. doi:10.1016/j.cmi.2020.04.026

28. Costanzo M, De Giglio MAR, Roviello GN. SARS-CoV-2: Recent Reports on Antiviral Therapies Based on Lopinavir/Ritonavir, Darunavir/Umifenovir, Hydroxychloroquine, Remdesivir, Favipiravir and Other Drugs for the Treatment of the New Coronavirus. Current medicinal chemistry . Apr 16 2020;doi:10.2174/0929867327666200416131117

29. Nasir M, Talha KA, Islam T, Saha SK, Selina F, Parveen RA. Use of Remdesivir in the Management of COVID-19: A Systematic Review on Current Evidences. Mymensingh medical journal : MMJ . Apr 2020;29(2):481-487.

30. Jorgensen SC, Kebriaei R, Dresser LD. Remdesivir: Review of pharmacology, pre-clinical data and emerging clinical experience for COVID-19. Pharmacotherapy . May 23 2020;doi:10.1002/phar.2429

31. Ye Z, Wang Y, Colunga-Lozano LE, et al. Efficacy and safety of corticosteroids in COVID-19 based on evidence for COVID-19, other coronavirus infections, influenza, community-acquired pneumonia and acute respiratory distress syndrome: a systematic review and meta-analysis. CMAJ : Canadian Medical Association journal $=$ journal de l'Association medicale canadienne . May 14 2020;doi:10.1503/cmaj.200645

32. Veronese N, Demurtas J, Yang L, et al. Use of Corticosteroids in Coronavirus Disease 2019 Pneumonia: A Systematic Review of the Literature. Frontiers in medicine . 2020;7:170. doi:10.3389/fmed.2020.00170

33. Halpin DMG, Singh D, Hadfield RM. Inhaled corticosteroids and COVID-19: a systematic review and clinical perspective. The European respiratory journal . May 2020;55(5)doi:10.1183/13993003.01009-2020

34. Puoci F. "Monoclonal-Type" Plastic Antibodies for COVID-19 Treatment: What Is the Idea? Journal of functional biomaterials . Jun 17 2020;11(2)doi:10.3390/jfb11020043

35. Marovich M, Mascola JR, Cohen MS. Monoclonal Antibodies for Prevention and Treatment of COVID19.Jama . Jun 15 2020;doi:10.1001/jama.2020.10245

36. Correa Giron C, Laaksonen A, Barroso da Silva FL. On the interactions of the receptor-binding domain of SARS-CoV-1 and SARS-CoV-2 spike proteins with monoclonal antibodies and the receptor ACE2. Virus research . Aug 2020;285:198021. doi:10.1016/j.virusres.2020.198021

37. Hung IF, Lung KC, Tso EY, et al. Triple combination of interferon beta-1b, lopinavir-ritonavir, and ribavirin in the treatment of patients admitted to hospital with COVID-19: an open-label, randomised, phase 2 trial. Lancet . May 30 2020;395(10238):1695-1704. doi:10.1016/S0140-6736(20)31042-4

38. Khalili JS, Zhu H, Mak NSA, Yan Y, Zhu Y. Novel coronavirus treatment with ribavirin: Groundwork for an evaluation concerning COVID-19. Journal of medical virology . Jul 2020;92(7):740-746. doi:10.1002/jmv. 25798

39. Gimenez E, Albert E, Torres I, et al. SARS-CoV-2-reactive interferon-gamma-producing CD8 $(+)$ $\mathrm{T}$ cells in patients hospitalized with Coronavirus Disease 2019. Journal of medical virology . Jun 24 2020;doi:10.1002/jmv.26213

40. Mary A, Henaut L, Schmit JL, Lanoix JP, Brazier M. Therapeutic Options for Coronavirus Disease 2019 (COVID-19) - Modulation of Type I Interferon Response as a Promising Strategy? Frontiers in public health . 2020;8:185. doi:10.3389/fpubh.2020.00185

41. Clark E, Guilpain P, Filip L, et al. Convalescent plasma for persisting Covid-19 following therapeutic lymphocyte depletion: a report of rapid recovery. British journal of haematology . Jun 27 2020;doi:10.1111/bjh.16981 
42. Wiwanitkit V. Convalescent plasma therapy in the treatment of COVID-19: some considerations: correspondence. International journal of surgery . Jun 22 2020;doi:10.1016/j.ijsu.2020.06.029

43. Bamba C, Singh SP, Choudhury S. Can mesenchymal stem cell therapy be the interim management of COVID-19? Drug discoveries $\&$ therapeutics . Jun 16 2020;doi:10.5582/ddt.2020.03032

44. Liu Z, Yuan X, Liu M, et al. Antimicrobial Peptide Combined with BMP2-Modified Mesenchymal Stem Cells Promotes Calvarial Repair in an Osteolytic Model. Molecular therapy : the journal of the American Society of Gene Therapy . Jan 3 2018;26(1):199-207. doi:10.1016/j.ymthe.2017.09.011

45. Liu Z, Yuan X, Fernandes G, et al. The combination of nano-calcium sulfate/platelet rich plasma gel scaffold with BMP2 gene-modified mesenchymal stem cells promotes bone regeneration in rat critical-sized calvarial defects. Stem cell research \& therapy . May 25 2017;8(1):122. doi:10.1186/s13287-017-0574-6

46. Fernandes G, Wang C, Yuan X, Liu Z, Dziak R, Yang S. Combination of Controlled Release Platelet-Rich Plasma Alginate Beads and Bone Morphogenetic Protein-2 Genetically Modified Mesenchymal Stem Cells for Bone Regeneration. Journal of periodontology . Apr 2016;87(4):470-80. doi:10.1902/jop.2016.150487

47. Eskazan AE. Chronic myeloid leukaemia and the use of tyrosine kinase inhibitors in the days of COVID-19 pandemic. British journal of clinical pharmacology . May 7 2020;doi:10.1111/bcp.14353

48. Peterson D, Damsky W, King B. The use of Janus kinase inhibitors in the time of severe acute respiratory syndrome coronavirus 2 (SARS-CoV-2). Journal of the American Academy of Dermatology . Jun 2020;82(6):e223-e226. doi:10.1016/j.jaad.2020.03.099

49. La Rosee F, Bremer HC, Gehrke I, et al. The Janus kinase 1/2 inhibitor ruxolitinib in COVID-19 with severe systemic hyperinflammation. Leukemia . Jul 2020;34(7):1805-1815. doi:10.1038/s41375-020-0891-0

50. Praveen D, Puvvada RC, M VA. Janus kinase inhibitor baricitinib is not an ideal option for management of COVID-19. International journal of antimicrobial agents . May 2020;55(5):105967. doi:10.1016/j.ijantimicag.2020.105967

51. Grover A, Oberoi M. A systematic review and meta-analysis to evaluate the clinical outcomes in COVID19 patients on angiotensin-converting enzyme inhibitors or angiotensin receptor blockers. European heart journal Cardiovascular pharmacotherapy . Jun 15 2020;doi:10.1093/ehjcvp/pvaa064

52. Shyh GI, Nawarskas JJ, Cheng-Lai A. Angiotensin-Converting Enzyme Inhibitors and Angiotensin Receptor Blockers in Patients With Coronavirus Disease 2019: Friend or Foe?Cardiology in review . Jul/Aug 2020;28(4):213-216. doi:10.1097/CRD.0000000000000319

53. UHMS Position Statement: Hyperbaric Oxygen (HBO2) for COVID-19 Patients. Undersea $E_{3}$ hyperbaric medicine : journal of the Undersea and Hyperbaric Medical Society, Inc. Second Quarter 2020;47(2):297-298.

54. Guo D, Pan S, Wang M, Guo Y. Hyperbaric oxygen therapy may be effective to improve hypoxemia in patients with severe COVID-2019 pneumonia: two case reports. Undersea Es hyperbaric medicine : journal of the Undersea and Hyperbaric Medical Society, Inc . Second Quarter 2020;47(2):181-187.

55. Moon RD, Weaver LK. Hyperbaric oxygen as a treatment for COVID-19 infection? Undersea $\&$ hyperbaric medicine: journal of the Undersea and Hyperbaric Medical Society, Inc. Second Quarter 2020;47(2):177-179.

56. Harch PG. Hyperbaric oxygen treatment of novel coronavirus (COVID-19) respiratory failure.Medical gas research . Apr-Jun 2020;10(2):61-62. doi:10.4103/2045-9912.282177

57. Lo JJ, Wang SC, Lee HY, et al. Proactive COVID-19 Infection Prevention Measures in a Hyperbaric Oxygen Therapy Center. Medicina . May 27 2020;56(6)doi:10.3390/medicina56060261

58. De Maio A, Hightower LE. COVID-19, acute respiratory distress syndrome (ARDS), and hyperbaric 
oxygen therapy (HBOT): what is the link? Cell stress $\&$ chaperones . May 18 2020;doi:10.1007/s12192-02001121-0

59. Thibodeaux K, Speyrer M, Raza A, Yaakov R, Serena TE. Hyperbaric oxygen therapy in preventing mechanical ventilation in COVID-19 patients: a retrospective case series. Journal of wound care. May 1 2020;29(Sup5a):S4-S8. doi:10.12968/jowc.2020.29.Sup5a.S4

60. Barnabas RV, Brown E, Bershteyn A, et al. Efficacy of hydroxychloroquine for post-exposure prophylaxis to prevent severe acute respiratory syndrome coronavirus 2 (SARS-CoV-2) infection among adults exposed to coronavirus disease (COVID-19): a structured summary of a study protocol for a randomised controlled trial. Trials . Jun 3 2020;21(1):475. doi:10.1186/s13063-020-04446-4

Table 1: Summary of interventional clinical trials conducted worldwide for the management of COVID-19

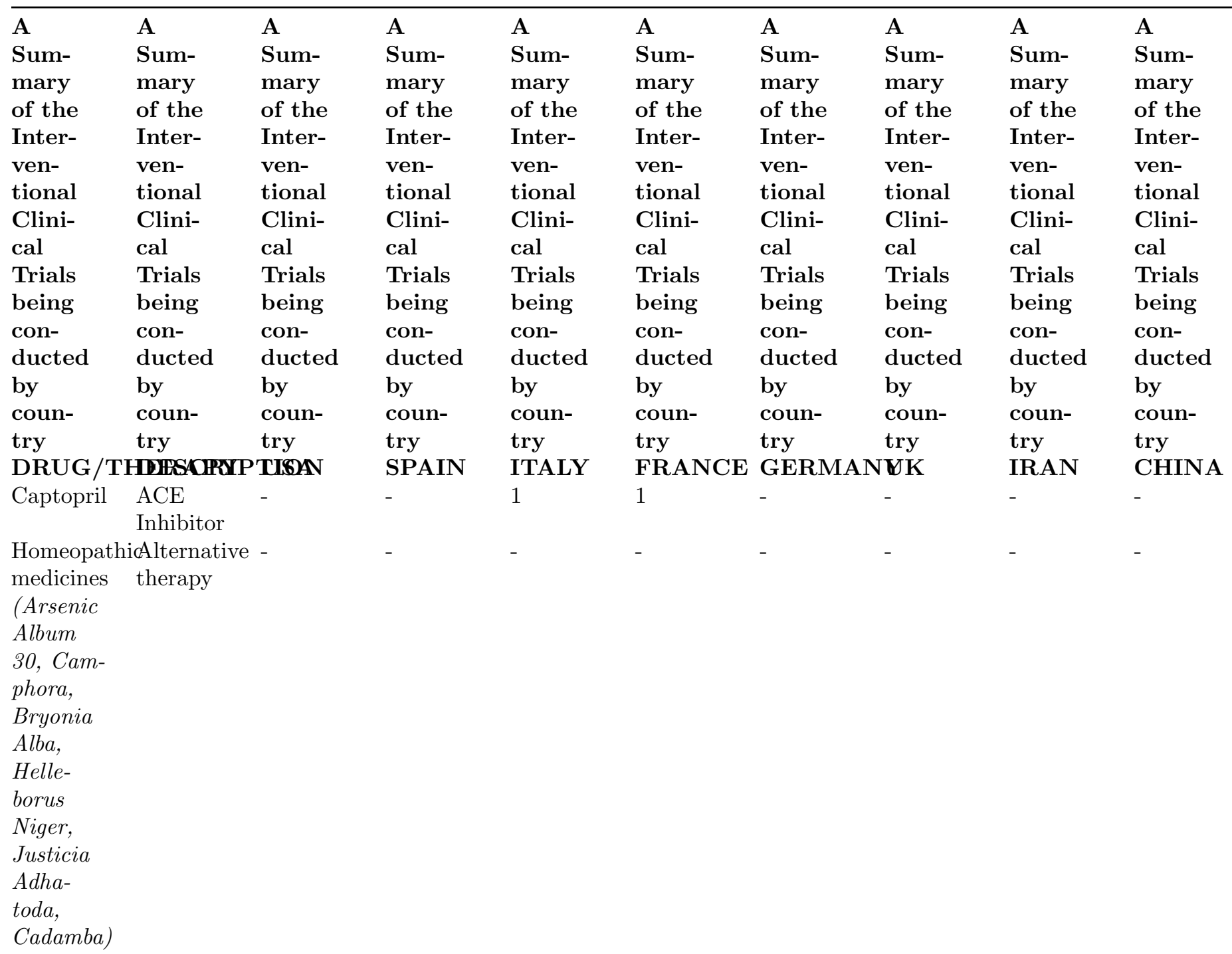




\begin{tabular}{|c|c|c|c|c|c|c|c|c|c|}
\hline $\begin{array}{l}\text { Ayurvedic } \\
\text { medicines } \\
\text { (Yashti- } \\
\text { madhu, } \\
\text { Ayush- } \\
64, \\
\text { Ashwa- } \\
\text { gandha, } \\
\text { Guduchi } \\
\text { and } \\
\text { Pippali, } \\
\text { Zingivir- } \\
\text { H) }\end{array}$ & $\begin{array}{l}\text { Alternative - } \\
\text { therapy }\end{array}$ & & - & - & - & - & - & - & - \\
\hline $\begin{array}{l}\text { Ozone } \\
\text { Therapy }\end{array}$ & $\begin{array}{l}\text { Alternative - } \\
\text { therapy }\end{array}$ & & 1 & - & - & - & - & - & 1 \\
\hline Losartan & $\begin{array}{l}\text { Angiotensin } 4 \\
\text { Recep- } \\
\text { tor } \\
\text { Blocker }\end{array}$ & & - & - & - & - & - & - & - \\
\hline Telmisartan & $\begin{array}{l}\text { Angiotensin } 1 \\
\text { Recep- } \\
\text { tor } \\
\text { Blocker }\end{array}$ & & - & - & - & - & - & - & - \\
\hline Valsartan & $\begin{array}{l}\text { Angiotensin - } \\
\text { Recep- } \\
\text { tor } \\
\text { Blocker }\end{array}$ & & - & - & - & 1 & - & - & - \\
\hline Favipiravir & $\begin{array}{l}\text { Anti- } \\
\text { viral }\end{array}$ & 2 & - & - & - & - & - & 1 & 7 \\
\hline Remdesivir & $\begin{array}{l}\text { Anti- } \\
\text { viral }\end{array}$ & 3 & - & - & 3 & 2 & 3 & - & 2 \\
\hline Umifenovir & $\begin{array}{l}\text { Anti- } \\
\text { viral }\end{array}$ & - & - & - & - & - & - & 1 & - \\
\hline Azithromyci & $\begin{array}{l}\text { inAnti- } \\
\text { biotic }\end{array}$ & - & - & - & - & - & - & 1 & - \\
\hline Heparin & $\begin{array}{l}\text { Anti- } \\
\text { coagulant }\end{array}$ & - & - & - & 2 & - & - & - & 2 \\
\hline $\begin{array}{l}\text { Tranexamic } \\
\text { acid }\end{array}$ & $\begin{array}{l}\text { Anti- } 2 \\
\text { fibrinolytic }\end{array}$ & 2 & - & - & - & - & - & - & - \\
\hline Colchicine & $\begin{array}{l}\text { Anti- } \\
\text { gout }\end{array}$ & 1 & - & - & - & - & 1 & - & - \\
\hline Niclosamide & $\begin{array}{l}\text { Anti- } \\
\text { helminthic }\end{array}$ & - & - & - & - & - & - & - & - \\
\hline Aescin & $\begin{array}{l}\text { Anti- } \\
\text { inflammatory } \\
\text { Anti- } \\
\text { oedematous }\end{array}$ & & - & 1 & - & - & - & - & - \\
\hline $\begin{array}{l}\text { Hydrochloro } \\
\text { sul- } \\
\text { fate/ } \\
\text { Chloroquine }\end{array}$ & $\begin{array}{l}3 \\
\text { malarial }\end{array}$ & 33 & - & - & 9 & 1 & 3 & - & 32 \\
\hline
\end{tabular}




\begin{tabular}{|c|c|c|c|c|c|c|c|c|}
\hline Ivermectin & $\begin{array}{l}\text { Anti- } \\
\text { parasitic }\end{array}$ & - & - & - & - & - & - & - \\
\hline Atovaquone & $\begin{array}{l}\text { Anti- } \\
\text { protozoal }\end{array}$ & 1 & - & - & - & - & - & - \\
\hline $\begin{array}{l}\text { Povidone- } \\
\text { Iodine }\end{array}$ & $\begin{array}{l}\text { Anti- } \\
\text { septic }\end{array}$ & 2 & - & - & - & - & - & - \\
\hline Vazegapant & $\begin{array}{l}\text { CGRP } \\
\text { recep- } \\
\text { tor } \\
\text { antagonist }\end{array}$ & 1 & - & - & - & - & - & - \\
\hline DRUG & DESCRIF & TI6AN & SPAIN & ITALY & FRANCE & GERMANVK & IRAN & CHINA \\
\hline Dexamethas & schorticoster & oid & - & - & 2 & - & - & - \\
\hline Methylpred & InGroitinicoster & oild & - & - & - & - & - & 8 \\
\hline Prednisone & Corticoster & oid & - & - & 1 & - & - & - \\
\hline Linagliptin & $\begin{array}{l}\text { DPP4 } \\
\text { Inhibitor }\end{array}$ & 1 & - & - & - & - & - & - \\
\hline $\begin{array}{l}\text { Dornase } \\
\text { alfa }\end{array}$ & $\begin{array}{l}\text { Enzyme } \\
\text { (Biosyn- } \\
\text { thetic } \\
\text { DNase1) }\end{array}$ & 1 & - & - & - & - & - & - \\
\hline Deferoxamiı & $\begin{array}{l}\text { nHeavy } \\
\text { metal } \\
\text { antagonist }\end{array}$ & - & - & - & - & - & 1 & - \\
\hline Lopinavir/R & $\begin{array}{l}\text { Ritowavir } \\
\text { pro- } \\
\text { tease } \\
\text { inhibitor }\end{array}$ & 1 & - & - & - & - & - & 14 \\
\hline Oestrogen & $\begin{array}{l}\text { Hormone } \\
\text { therapy }\end{array}$ & 1 & - & - & - & - & - & - \\
\hline $\begin{array}{l}\text { IFN } \\
\text { Beta } \\
1 \mathrm{~A} \mathrm{\&} \\
1 \mathrm{~B}\end{array}$ & Immunome & dulators & - & - & - & 1 & 2 & - \\
\hline $\begin{array}{l}\text { NK } \\
\text { cells }\end{array}$ & Immunome & deulators & - & 1 & - & - & - & 1 \\
\hline $\begin{array}{l}\text { PEG- } \\
\text { IFN- } \\
\text { Lamba }\end{array}$ & Immunomo & dRllators & - & - & - & - & - & - \\
\hline Sirolimus & Immunosul & pplressant & - & - & - & - & - & - \\
\hline Acalabrutin & $\begin{array}{l}\text { iKinase } \\
\text { Inhibitor }\end{array}$ & - & 1 & - & - & - & - & - \\
\hline Baricitinib & $\begin{array}{l}\text { Kinase } \\
\text { Inhibitor }\end{array}$ & 1 & - & - & - & - & - & - \\
\hline Imatinib & $\begin{array}{l}\text { Kinase } \\
\text { Inhibitor }\end{array}$ & - & - & - & - & - & - & - \\
\hline $\begin{array}{l}\text { Nintedanib } \\
\text { esilate }\end{array}$ & $\begin{array}{l}\text { Kinase } \\
\text { Inhibitor }\end{array}$ & - & - & - & - & - & - & 13 \\
\hline Ruxolitinib & $\begin{array}{l}\text { Kinase } \\
\text { Inhibitor }\end{array}$ & 1 & - & - & - & - & - & - \\
\hline Bevacizuma & $\begin{array}{l}\text { AMonoclona } \\
\text { Antibodies }\end{array}$ & & - & 1 & - & - & - & 20 \\
\hline
\end{tabular}


Clazakizumablonoclonal 1 Antibodies

Gimsilumab Monoclonal 1 Antibodies

Itolizumab Monoclonal Antibodies

Leronlimab Monoclonal 2 Antibodies

MeplazumabMonoclonal Antibodies

Nivolumab Monoclonal Antibodies

Sarilumab Monoclonal 2 Antibodies

Tocilizumab Monoclonal 4 Antibodies

Tradipitant Nerokinin- 1 1 antagonist

Ribavirin Nucleoside inhibitors

ConvalescentPassive 8

plasma Im-

mune Therapy

LeflunomidePyrimidine 1 synthe-

sis inhibitor

Selinexor Selective 1

in-

hibitor

of

nuclear

trans-

port (SINE)

Nitric Selective 3

oxide Pul-

inhalation monary vasodilator

DRUG DESCRIPTISAN

SPAIN

\section{ITALY}

FRANCE GERMANUK

IRAN

CHINA

FluvoxamineSelective 1 serotonin reuptake inhibitor

DapagliflozinSGLT2 inhibitors 


\begin{tabular}{|c|c|c|c|c|c|c|c|c|c|}
\hline $\begin{array}{l}\text { Human } \\
\text { amni- } \\
\text { otic } \\
\text { fluid }\end{array}$ & $\begin{array}{l}\text { Stem } \\
\text { cell } \\
\text { therapy }\end{array}$ & 1 & - & - & - & - & - & - & - \\
\hline Mesenchyma & $\begin{array}{l}\text { aStem } \\
\text { cell } \\
\text { therapy }\end{array}$ & 5 & - & - & 1 & - & - & 1 & 1 \\
\hline $\begin{array}{l}\text { Hyperbaric } \\
\text { Oxygen }\end{array}$ & $\begin{array}{l}\text { Systemic } \\
\text { oxygen } \\
\text { therapy }\end{array}$ & 2 & - & - & 1 & - & - & - & 7 \\
\hline $\begin{array}{l}\text { Bu-Fei- } \\
\text { Huo- } \\
\text { Xue } \\
\text { capsule }\end{array}$ & $\begin{array}{l}\text { Traditional } \\
\text { ther- } \\
\text { apy } \\
\text { (Chinese) }\end{array}$ & - & - & - & - & - & - & - & 1 \\
\hline $\begin{array}{l}\text { Tan Re } \\
\text { Quing } \\
\text { injection }\end{array}$ & $\begin{array}{l}\text { Traditional } \\
\text { ther- } \\
\text { apy } \\
\text { (Chinese) }\end{array}$ & - & - & - & - & - & - & - & 1 \\
\hline $\begin{array}{l}\text { SSV } \\
\text { formulation }\end{array}$ & $\begin{array}{l}\text { Traditional } \\
\text { ther- } \\
\text { apy } \\
\text { (Indian) }\end{array}$ & - & - & - & - & - & - & - & - \\
\hline $\begin{array}{l}\text { BCG } \\
\text { vaccine }\end{array}$ & $\begin{array}{l}\text { Vaccine } \\
\text { (re- } \\
\text { purposed) }\end{array}$ & 1 & - & - & 1 & - & - & - & - \\
\hline $\begin{array}{l}\text { Mycobacteri } \\
\text { w }\end{array}$ & $\begin{array}{l}\text { (re- } \\
\text { purposed) }\end{array}$ & - & - & - & - & - & - & - & - \\
\hline Vaccine(s) & $\begin{array}{l}\text { Vaccine } \\
\text { (new) }\end{array}$ & 4 & - & - & - & 1 & 1 & - & 3 \\
\hline Aviptadil & $\begin{array}{l}\text { Vasoactive } \\
\text { intesti- } \\
\text { nal } \\
\text { polypeptide }\end{array}$ & 1 & - & - & - & - & - & - & - \\
\hline $\begin{array}{l}\text { Vitamin } \\
\mathrm{C}\end{array}$ & $\begin{array}{l}\text { Nutritive } \\
\text { Agent }\end{array}$ & 3 & - & - & - & - & - & - & 2 \\
\hline Actilyse & Thrombolyt & & - & - & - & - & 1 & - & - \\
\hline
\end{tabular}

